than in other animals, and it is well known that in small ones heat delivery from a unit area of the sur. face of their bodies is greater than in large species. Therefore, the former need a better thermo-isolation. Consequently, the pelage of $M$. meridianus is of the greatest density and height, and the sebaceous glands and m.m. arrectores pilorum are well developed. By the density of its fur (as many as 280 hairs per $1 \mathrm{~mm} .{ }^{2}$ ) $M$. meridianus surpasses many other animals; for example, the Castor fiber has 230 hairs on the same skin area, Myocastor coypus 150, Sc. vulgaris 100 hairs, and so on. The composition of hair tufts in $M$. meridianus is as follows: 1 axial hair, 3-5 intermediate and 8-11 wool hairs.

In winter, $R$. opimus does not leave its burrow at low temperatures. Its fur is thinner than in $M$. meridianus (180 hairs per $1 \mathrm{~mm} .^{2}$ of skin), the composition of hair tufts being as follows: 1 axial hair, 4-5 intermediate and 5-9 wool hairs.

Although $S p$. leptodactylus are less sensitive to cold than $R$. opimus, on frosty days they either remain in their burrows or leave them for a short time only. Their pelage is also rather rare ( 130 hairs per $1 \mathrm{~mm} .{ }^{2}$ ) and the hair tufts consist of 1 axial, 2-5 intermediate and 4-5 wool hairs.

The deserts of Central Asia are characterized by sharp seasonal changes of their climate, according to which the structure of the cutaneous covering becomes altered in desert animals. I have examined the seasonal variability of the skin only in $S p$. leptodactylus and $R$. opimus. Their epidermis is thinner in winter than in summer; for example, on the back of $S p$. leptodactylus it reaches at an average $20 \mu$ in winter, while in summer it is $40 \mu$ thick. In $R$. opimus the epidermis is only $7 \mu$ thick in winter, rising to $44 \mu$ in summer. The number of cell rows in the Malpighian layer increases twice or three times in summer. However, the corneous layer is thicker in winter than in summer, becoming nearly twice as thick in $S p$. leptodactylus and three times thicker in $R$. opimus. The same is known to occur in most mammals. Sweat glands in the skin of the soles of paws are not large in winter, the diameter of the gland lumen averaging $11 \mu$ in $S p$. leptodactylus and $5 \mu$ in $R$. opimus. In summer the lumen diameter of $S p$. leptodactylus increases roughly five times, and that of $R$. opimus seven times. The glands themselves become much larger and more sinuous; the cells of their secretory parts grow likewise in size. In the dermis and in the subcutaneous cellular tissue the number of large blood vessels increases in summer. At that time there are many cellular elements in the upper sections of the dermis. The pelage becomes much rarified in summer. It is nearly three times sparser in Sp. leptodactylus, having 130 hairs per 1 $\mathrm{mm} .{ }^{2}$ in winter and 50 in summer. In $R$. opimus it is twice as thin: 180 hairs in winter and 90 in summer. Such a reduction occurs chiefly at the expense of wool hairs. Thus, in $S p$. leptodactylus there remains only 2 hairs in the hair tuft in summer instead of 4-5 hairs present therein in winter; in $R$. opimus also only 2 instead of 5-9, in $C$. pygmaeus 2-3, and in C. suslicus 4-9 hairs. In summer the hairs are much reduced in size. In $S p$. leptodactylus, as distinct from most mammals, the axial and particularly the directing hairs increase considerably in breadth during summer. They decrease 3-4 times in length, but become either twice as broad (directing hairs) or $1 \cdot 1-1 \cdot 7$ times broader (axial hairs).

${ }^{1}$ Kazbekova, E. P., Arch. Biol. Sci. (U.S.S.R.), 64 (1941).

${ }^{2}$ Kurlandskaya, E. B., Bull. Exp. Biol. and Merd.(U.S.S.R.),11, 6 (1941).

s Dienesman, L. G., Problems of Physical Geography (U.S.S.R.), 14 (1949).

- Krüger, P., Biologisches Zentralblatt, 49, B, 2 (1929).

- Secerov, S., Archiv. Entwicklungsmechanik der Organismen, 34, 4 (1912).

' Shimanko, I. I., 'Medicine', No. 11 (U.S.S.R.) (1930).

\title{
OBITUARIES
}

\section{Prof. A. M. Tyndall, C.B.E., F.R.S.}

Arthur Mannering Tyndall, whose death at the age of eighty occurred at his home in Bristol on October 29, 1961, devoted the whole of his adult life to the University of Bristol and especially to the development within it of the Henry Herbert Wills Physical Laboratory in the foundation of which he played a decisive part.

Tyndall was born in Bristol in 1881 and went to school there. His only early instruction in science was restricted to a few lessons in chemistry in his last two terms at school, and it was with the intention of studying that subject that he entered what was then University College, Bristol, in 1898, after successfully gaining the only scholarship offered at that time by the City of Bristol for admission to the College. He soon found himself under the influence of an outstanding teacher, Prof. A. P. Chattock, by whom he was profoundly impressed, and he was led to transfer his main interest to physics. He read for the external degree of the University of London with honours in physics, taking chemistry and mathematics in addition.

Soon after graduating, Tyndall was appointed assistant lecturer in physics in the University College, Bristol, and later, lecturer in the University when it was founded in 1909. He was acting head of the
Department of Physies during 1910-1919, and Henry Overton Wills professor in the University from 1919 until his retirement in 1948. For more than twenty years, from 1927 until 1948, he was director of the Physics Laboratory, and after his retirement, as professor emeritus, he maintained a constant and creative interest in the Laboratory and its members until the day of his death.

Most of Tyndall's scientific work was in the field of the discharge of electricity in gases. Whilst a lecturer, he had worked with Chattock to determine the masses of the gaseous ions by observing the differences of pressure set up as a result of a pointdischarge in hydrogen at atmospheric pressure. They reached the conclusion that the negative ions are electrons--thus confirming a result arrived at independently by Townsend-and that the positive ions are charged atoms.

In the early 1920's, Tyndall began a long series of experiments on the mobility of the positive ions. The subject at that time was very confused, for all the early experimenters had used apparatus sealed with wax, in which it was impossible to maintain a gas in a state of high purity. Tyndall and a number of young colleagues developed several original methods for measuring the mobility, and, taking advantage of the newly developed vacuum techniques, they constructed apparatus which could 
be rigorously degassed. Significant measurements in a large number of pure gases with a variety of ions of known types were thus made, and effects due to the attachment of molecules of polar impurities, such as had vitiated the early work, were clearly demonstrated. It was for this work that in 1933 he was elected a Fellow of the Royal Society. Tho main results of these studies were described by Tyndall in a monograph on The Mobility of Ions in Gases.

Even moro important than 'Tyndall's scientific work was his contribution to the foundation and development of the Henry Horbert Wills Physical Laboratory. It is a long and fascinating story which began with his daily walk to the Laboratory in the company of the donor. The original intention was to build a small structure to house a badly needed new battery; but with tho growth of mutual confidence, the programmo was enlarged, and it eventually lod to tho gift of the present building.

At the formal opening of the spacious new Labor. atory, Tyndall was warned by some of the eminent visitors that what makes a good laboratory is not bricks and mortar alone, but the quality of the men in it. He sometimes referred to this incident with a trace of irony, but it was indeed largely owing to his remarkable personal qualities that the Laboratory developed and flourished. Ho created an atmosphere of ease and warrn humanity which helped people to do their bost, and he showed a constant disinterestod solicitude that the work of his colleagues and students should receive proper recognition.

It scems unlikely that in modern conditions in Great Britain another laboratory will again owe so much in its foundation and development to a single man. Cortainly British physics will owe him a debt for a long time to come for the example which he set and for his influence on his colleagues and pupils who included, to name only a few, L. P. Bates, C. IR. Burch, F. C. Frank, H. Fröhlich, R. W. Gurnoy, W. Heitler, W. Herzberg, L. C. Jackson, J. E. LennardJones, H. London, A. C. B. Lovell, N. F. Mott, S. H. Piper, H. W. B. Skinner and W. Sucksmith.

$$
\text { C. F. Powklt }
$$

\section{Dr. W. B. Turrill, O.B.E., F.R.S.}

THE sudden death of Dr. W. B. Turrill, who collapsed and died in his house at Richmond on Decembor 15, 1961, has removed one whose rocord of achievoment placed him fairly in the lino of succes. sion of great Kew botanists. For more than fifty years ho was activoly associated with the Royal Botanic Gardens to which he gave dovotod sorvice and gained wide recognition and high distinction.

Turrill was born at Woodstock on June 14, 1890, and thore is no doubt that in his boyhood ho drow inspiration and delight from the countryside around him which afforded fruitful hunting and excellent training for his bent towards natural history. Ho was odueated at Oxford High School whero he was a contemporary of Lawrence of Arabia of whom he had vivid recollections. When he was sixteen ho started work in the Fielding Herbarium of the University of Oxford and here, with thes specinl cncouragement of the late Dr. (*. Claridge I)ruce and under the guidanee of symprathetic collcagues, Dr. 'Turrill's lovo of plants was greatly stimulated and his botanical ambitions wore fired. 'Three yoars lator, in 1909, he entered the Kew Herbarium as a technical assistant, and in sorting and handling specimens from all ovor the world under the supervision of the leading botan- ists he acquired an excellent knowledge of all plant groups and a reputation for concontrated and thorough work. In his first year at Kew he published his first botanical paper and, except for two years during his military service, he maintained a steady and incroasing flow of publications right up to the time of his death. In all ho was rosponsible for more than 500 published botanical contributions.

During his early years at Kew, Turrill attended classes in botany at the Chelsoa Polytechnic and these studies led to the degree of B.Sc. with first-class honours in botany in 1915 , followed by the M.Sc. in 1922 and eventually the D.S\% in 1928, the last. for his extensive studies of the plant-life of the Balkans.

In 1915 he became a permanent member of the Kow staff, but his career was soon interrupted when he joined the Forces and was sent on active service to Macedonia. It was there that he made his first arquaintance with a new flora, and this experience dotermined his main botanical interest. Whenever he could escape from his military duties he engaged in plant collecting and in a close study of tho vegetation around him. Only after the First World War was he able to make sevoral expeditions to other parts of the Balkans and the consolidated rosults wero published in his magnum opus, T'he Plant-Life of the Balkan Peninsula in 1929, a work which established his reputation as the leading authority on tho flora of south-east Europe.

At Kow he was placed in charge of various plant families including the Cyporaceae, of which he gained an expert knowledge, but latterly he became botanist in charge of the European Mediterranean collections. From his close observation of plants in the field and in the experimental garden, Turrill was convinced that for proper taxonomic understanding comprehonsivo and intensive studies of living and herbarium material was necessary. He developed this theme in a long succession of publications and lectures of which the most notable contributions were the two volumes written in collaboration with the lato $\mathrm{E}$. $\mathrm{M}$. Marsden-Jones on British Knapweeds (1954) and Bladder Campions (1957). He also published extonsively on Ranunculus, Saxifraga and Taraxacum, and his studies on the British flora culminated in his British Plant Life (1948). Other notable works were his Pioneer Plant Geography (1953), The Royal Botanic Gardens, Kew (1959) and Vistas in Botany (1959) which he devised and cdited on the occasion of the bicentenary of Kow. In 1946, Turrill was appointed keeper of the Herbarium and Library, and he held that position until his retirement in 1957.

'Turrill's knowledge, derived from his personal researches and very wide reading, was armazingly extensive and he dolighted in discussion on all kinds of botanical topics with tho many experts who habitually visit Kew. He was also a gifted teacher and for a time he lectured in the evenings at Chelsea. Yolytechnic on evolution, horedity and ecology, and for many years he taught these subjects to the student gardeners at Kew.

T'urrill's outstanding sorviees to his scienco were fitly rocognized in 1958 when ho was admitted to the fellowship of the Royal Society and when, in the same year, he recoived from the Linnoun Society the Linnean Gold Medal. He was honoured by the Royal ITorticultural Society for his active interest in horticulture, particularly for his work on Lilium and Fritillaria, and he also edited Curtis's Rotanical 